\title{
Hypouricaemia and increased renal urate clearance associated with hyperparathyroidism
}

\author{
T. GIBSON, H. P. SIMS, AND S. A. JIMENEZ \\ From the Department of Medicine, Rheumatology Section, University of Pennsylvania School of Medicine \\ and the Philadelphia General Hospital, Pennsylvania
}

\begin{abstract}
Gibson, T., Sims, H. P., and Jimenez, S. A. (1976). Annals of the Rheumatic Diseases, 35, 372-376. Hypouricaemia and increased renal urate clearance associated with hyperparathyroidism. A 64-year-old female was found to have hypouricaemia, with serum uric acid ranging from $0 \cdot 06-0 \cdot 12 \mathrm{mmol} / 1(1 \cdot 1-2 \cdot 0 \mathrm{mg} / 100 \mathrm{ml})$, associated with an increased urate clearance of $48.9 \mathrm{ml} / \mathrm{min}$ and hyperparathyroidism. Known causes of increased uric acid clearance were excluded. Pyrazinamide reduced urate clearance dramatically to $2 \cdot 1 \mathrm{ml} / \mathrm{min}$, suggesting that the tubular defect was either one of increased secretion or a failure of postsecretory reabsorption. No other tubular abnormality was apparent except diminished urine concentrating ability. Hypouricaemia has not been previously reported in association with hyperparathyroidism and a mechanism relating the two disorders could not be readily postulated. The tubular defect shown in this instance resembled that reported in association with Wilson's disease and Hodgkin's disease. This case and earlier reports of isolated tubular defects of uric acid handling enhance our understanding of uric acid excretion.
\end{abstract}

In general, hypouricaemia may be considered the consequence of either excessive urate excretion or defective urate synthesis (Healey, Skeith, and Simkin, 1974). The most common cause can be attributed to increased uric acid excretion by various drugs (Ramsdell and Kelley, 1973). Hyperexcretory mechanisms may also explain the hypouricaemia reported in association with liver disease (Schlosstein and others, 1974), bronchial carcinoma (Weinstein, Irreverre, and Watkins, 1965), and Hodgkin's disease (Bennett and others, 1972). Hyperuricosuria related to multiple renal tubular defects as in the hereditary or acquired forms of Fanconi's syndrome (Lee and others, 1972) or Wilson's disease (Wilson and Goldstein, 1973) may also cause hypouricaemia. In addition, there are reports of subjects with hypouricaemia and increased renal urate clearance attributed to isolated renal tubular defects (Praetorius and Kirk, 1950; Khachadurian and Arslanian,
1973). We report the investigation of a patient with: consistent and long-standing low serum uric acid3. values in whom increased urate clearance was associated with hyperparathyroidism.

\section{Case report}

A 64-year-old white female presented in 1959 with polyarthralgia. Several years earlier she had been treated으․ for a duodenal ulcer but had otherwise enjoyed good health. Her mother had a history of urinary calculi ando her father had died of ischaemic heart disease. She had onen daughter in good health. There was no history of con-N sanguinity. In 1960 the patient had a myocardial infarct ${ }^{\omega}$ and in 1963 xanthomata of both Achilles' tendons were noted together with a fasting serum cholesterol of $8.16 \mathrm{mmol} / \mathrm{l}(316 \mathrm{mg} / 100 \mathrm{ml})$. During the initial in-क vestigation two consecutive serum uric acid values mea-? sured by an automated colorimetric method were $0 \cdot 150$ $\mathrm{mmol} / \mathrm{l}(2.5 \mathrm{mg} / 100 \mathrm{ml})$ and $0.12 \mathrm{mmol} / 1(2.0 \mathrm{mg} / \mathrm{O}$ $100 \mathrm{ml}$ ). In 1968, the hypercholesterolaemia was treated with clofibrate, the serum cholesterol level falling to 6.07ब 
$\mathrm{mmol} / 1$ (235 $\mathrm{mg} / 100 \mathrm{ml})$. Low serum uric acid values as measured by the colorimetric technique persisted and were still apparent 6 months after stopping clofibrate. The mean of eight separate estimations during this period was $0 \cdot 14 \mathrm{mmol} / \mathrm{l}(2 \cdot 3 \mathrm{mg} / 100 \mathrm{ml})$, and the mean of three separate urine uric acid estimations was high at $4 \cdot 13$ $\mathrm{mmol} / \mathrm{l}(695 \mathrm{mg})$ per 24 hours. At the time of these investigations she was taking no medication.

In 1973 serum calcium was $2.98 \mathrm{mmol} / 1(11.9 \mathrm{mg} /$ $100 \mathrm{ml}$ ) (normal $2 \cdot 25-2 \cdot 7 \mathrm{mmol} / \mathrm{l}$ ) and serum phosphate $0 \cdot 74 \mathrm{mmol} / 1(2 \cdot 3 \mathrm{mg} / 100 \mathrm{ml})$ (normal 0.97-1.45 mmol $/ 1$ ). Calcium metabolism was further evaluated during a hospital admission. The initial symptoms of arthralgia had persisted but there was no history of polyuria or renal colic and examination, including a slit lamp view of her eyes, was normal. Investigations showed fasting serum calcium $2.9 \mathrm{mmol} / 1(11.6 \mathrm{mg} / 100 \mathrm{ml})$; serum inorganic phosphate $0.77 \mathrm{mmol} / \mathrm{l}(2.4 \mathrm{mg} / 100 \mathrm{ml})$; serum alkaline phosphatase $49 \mathrm{mU} / \mathrm{ml}$ (normal 30-85 mU/ml); blood urea $6.7 \mathrm{mmol} / \mathrm{l}(40 \mathrm{mg} / 100 \mathrm{ml})$; serum creatinine $71 \mu \mathrm{mol} / 1(0.8 \mathrm{mg} / 100 \mathrm{ml})$; creatinine clearance $92 \mathrm{ml} /$ min; serum uric acid by the colorimetric method $0 \cdot 13$ $\mathrm{mmol} / \mathrm{l}(2.4 \mathrm{mg} / 100 \mathrm{ml})$; urate clearance $16.9 \mathrm{ml} / \mathrm{min}$; serum magnesium by atomic absorption spectrophotometry $0.94 \mathrm{mmol} / 1(2.3 \mathrm{mg} / 100 \mathrm{ml})$; fasting serum cholesterol $8.03 \mathrm{mmol} / 1(310 \mathrm{mg} / 100 \mathrm{ml})$; serum triglyceride $2.43 \mathrm{mmol} / 1$ (215 $\mathrm{mg} / 100 \mathrm{ml})$. Lipoprotein electrophoresis showed a type II hyperlipoproteinaemia. On an unrestricted diet urine calcium excretion was $8.95 \mathrm{mmol} / 24 \mathrm{~h}$ (358 $\mathrm{mg} / 24 \mathrm{~h}$ ). Phosphate clearance was $44.9 \mathrm{ml} / \mathrm{min}$ and tubular reabsorption of phosphate $42 \%$. The index of phosphate excretion as modified by Nordin and Bulusu (1968) was 0.72 , higher than the normal of \pm 0.5 and in the hyperparathyroid range described by the same authors. Circulating parathormone as measured by radioimmunoassay using antisera to bovine parathormone was $515 \mathrm{pg} / \mathrm{ml}$ (normal up to $500 \mathrm{pg} / \mathrm{ml}$ ).

Radiological survey of the skeleton showed chondrocalcinosis of the symphysis pubis, the right knee, and both hips, but no evidence of bone resorption. An intravenous urogram was normal but barium meal showed scarring of the duodenal bulb. On the basis of these findings a diagnosis of hyperparathyroidism was made. The patient was reluctant to undergo surgical treatment and the hypercalcaemia was treated with oral neutral phosphate. Serum calcium fell to $2.45 \mathrm{mmol} / 1$ $(9.8 \mathrm{mg} / 100 \mathrm{ml})$ after 5 months of therapy. The type II hyperlipoproteinaemia responded to a low cholesterol diet, falling to $7.56 \mathrm{mmol} / 1(292 \mathrm{mg} / 100 \mathrm{ml})$ over the same period. Uric acid clearance of $16.9 \mathrm{ml} / \mathrm{min}$ and a uric acid to creatinine clearance ratio of 0.18 were both abnormally high (Gutman and Yu, 1957). Because of these values and the consistently low serum uric acid the patient was readmitted for more detailed scrutiny of uric acid excretion and renal tubular function.

Routine haematological investigation was normal; serum calcium $2 \cdot 25 \mathrm{mmol} / 1(9.0 \mathrm{mg} / 100 \mathrm{ml})$; serum inorganic phosphate $0.71 \mathrm{mmol} / 1(2 \cdot 2 \mathrm{mg} / 100 \mathrm{ml})$; alkaline phosphatase $70 \mathrm{mU} / \mathrm{ml}$; serum electrolytes normal; serum bicarbonate $22 \mathrm{mmol} / 1(22 \mathrm{mEq} / \mathrm{l})$; total serum proteins $64 \mathrm{~g} / \mathrm{l}(6 \cdot 4 \mathrm{~g} / 100 \mathrm{ml})$; albumin $34 \mathrm{~g} / \mathrm{l}(3 \cdot 4 \mathrm{~g} / 100$ $\mathrm{ml})$, and protein electrophoresis normal. Liver function tests were normal; fasting blood glucose $5 \cdot 6 \mathrm{mmol} / \mathrm{l}(102$ $\mathrm{mg} / 100 \mathrm{ml})$; blood urea $8 \cdot 2 \mathrm{mmol} / 1(49 \mathrm{mg} / 100 \mathrm{ml})$; serum creatinine $88.4 \mu \mathrm{mol} / 1 \quad(1.0 \mathrm{mg} / 100 \mathrm{ml})$; creatinine clearance $61 \mathrm{ml} / \mathrm{min}$. The urine contained no glucose and 24-hour excretion of total reducing substances was $0.92 \mathrm{~g}$ (normal, less than $1 \mathrm{~g} / 24 \mathrm{~h}$ ). 24-Hour urine protein was $<0 \cdot 1 \mathrm{~g}$ and the pattern of urine amino acids (thin layer paper chromatography method) was normal. Urine sodium, chloride, and potassium excretion were also within normal limits. Urine copper excretion as measured by atomic absorption spectrophotometry was $0.99 \mu \mathrm{mol} /$ $24 \mathrm{~h}(63 \mu \mathrm{g} / 24 \mathrm{~h})$ (normal 0-1 $\cdot 7 \mu \mathrm{mol} / 24 \mathrm{~h})$; serum copper $14 \cdot 13 \mu \mathrm{mol} / 1(90 \mu \mathrm{g} / 100 \mathrm{ml})$ (normal $11 \cdot 0-21 \cdot 0 \mu \mathrm{mol} / \mathrm{l})$. Serum caeruloplasmin, assayed by a quantitative immunodiffusion technique, was 108 Meloy units (normal 45-91 Meloy units). Hydroxyproline excretion of 0.26 $\mathrm{mmol} / 24 \mathrm{~h}(35 \mathrm{mg} / 24 \mathrm{~h})$ was normal. After 12 hours of fluid deprivation urine osmolality was $422 \mathrm{mOsm} / 1$ (normal more than $500 \mathrm{mOsm} / \mathrm{l}$ ) and one hour after rapidly drinking $1500 \mathrm{ml}$ water, osmolality reached $98 \mathrm{mOsm} / \mathrm{l}$. An oral load of ammonium chloride (100 mg/ $\mathrm{kg}$ body weight) produced a minimum $\mathrm{pH}$ of $5 \cdot 1$ (normal $\mathrm{pH}<5 \cdot 5$; Wrong and Davies, 1959). The patient's daughter had normal serum uric acid, cholesterol, calcium, and phosphate levels. Her urate clearance and 24hour urine calcium and phosphate values were also normal.

\section{Special studies}

The patient was maintained on an essentially purine-free diet. Urine was collected over toluene and both serum and urine uric acid were measured by an enzymatic spectrophotometric technique (Liddle, Seegmiller, and Laster, 1959). Urine oxypurines were determined by the method of Klinenberg and others (1967). Pyrazinamide suppression was performed in the manner outlined by Steele and Rieselbach (1967) and the results interpreted as suggested by the same authors. The inulin priming dose was $2.6 \mathrm{~g}$ and a constant infusion rate of $40 \mathrm{mg} / \mathrm{min}$ was maintained throughout the test. After a one-hour equilibration period, clearances of inulin and uric acid were calculated for three 30 -minute periods before and four identical periods after oral administration of $3.0 \mathrm{~g}$ pyrazinamide. Urine flow of $10-11 \mathrm{ml} / \mathrm{min}$ was maintained by aggressive oral hydration and bladder catheterization was therefore unnecessary. Inulin concentrations of blood and urine were measured by the method of Roe, Epstein, and Goldstein (1967). Tubular secretion of uric acid was calculated as the maximal decrease in the amount of urate excreted per ml glomerular filtration rate after pyrazinamide administration. Fractional excretion of uric acid was expressed as the percentage of filtered urate excreted during the period of maximal pyrazinamide effect.

\section{Results}

On the third day of a purine-free diet, serum uric acid was $0.12 \mathrm{mmol} / 1(2.0 \mathrm{mg} / 100 \mathrm{ml})$, urine uric acid excretion $4.2 \mathrm{mmol} / 24 \mathrm{~h}(700 \mathrm{mg} / 24 \mathrm{~h})$, and uric acid clearance $29.2 \mathrm{ml} / \mathrm{min}$ per $1.73 \mathrm{~m}^{2}$. Using data provided by the pyrazinamide suppression test (Table), the average uric acid clearance during the control period was $48.9 \mathrm{ml} / \mathrm{min}$ per $1.73 \mathrm{~m}^{2}$. The average uric acid clearance to inulin clearance ratio $(\mathrm{C}$ urate $/ \mathrm{C}$ inulin $\times 100$ ) during the same period was $74.0 \%$, markedly higher than the normal value of 
Table Results of pyrazinamide suppression test

\begin{tabular}{|c|c|c|c|c|c|c|c|}
\hline $\begin{array}{l}\text { Period } \\
\text { (min) }\end{array}$ & $\begin{array}{l}\text { Serum } \\
\text { urate } \\
\text { mmol/l } \\
(\mathrm{mg} / 100 \mathrm{ml})\end{array}$ & $\begin{array}{l}\text { Volume } \\
\text { of urine } \\
(\mathrm{ml})\end{array}$ & $\begin{array}{l}\text { Cinulin } \\
(\mathrm{ml} / \mathrm{min} \text { per } \\
\left.1.73 \mathrm{~m}^{2}\right)\end{array}$ & $\begin{array}{l}\text { C urate } \\
(\mathrm{ml} / \mathrm{min} \text { per } \\
\left.1.73 \mathrm{~m}^{2}\right)\end{array}$ & $\begin{array}{l}\text { UVurate } \\
\begin{array}{l}\mathrm{mmol} / \mathrm{min} \\
(\mathrm{mg} / \mathrm{min})\end{array}\end{array}$ & $\begin{array}{l}\text { C uratel } \\
\text { Cinulin } \\
(\%)\end{array}$ & $\begin{array}{l}\text { UV urate } \mid \\
C \text { inulin } \\
\times 10^{-4} \mu \mathrm{mol} / \mathrm{ml} \\
(\mu \mathrm{g} / \mathrm{ml})\end{array}$ \\
\hline $0-30$ & \multirow{3}{*}{$\begin{array}{c}0.077 \\
(1 \cdot 3) \\
0.065 \\
(1 \cdot 1) \\
0.095 \\
(1 \cdot 6)\end{array}$} & 328 & 64 & $54 \cdot 5$ & \multirow{3}{*}{$\begin{array}{c}0.035 \\
(0.590) \\
0.029 \\
(0.498) \\
0.029 \\
(0.495)\end{array}$} & $85 \cdot 1$ & \multirow{3}{*}{$\begin{array}{c}5.46 \\
(9.21) \\
4.55 \\
(7.66) \\
4.08 \\
(6.97)\end{array}$} \\
\hline $30-60$ & & 305 & 65 & $54 \cdot 8$ & & $84 \cdot 3$ & \\
\hline $60-90$ & & 330 & 71 & $37 \cdot 4$ & & $52 \cdot 7$ & \\
\hline \multicolumn{8}{|c|}{ Pyrazinamide $3.0 \mathrm{~g}$ given at $90 \mathrm{~min}$ : } \\
\hline $90-120$ & $\begin{array}{c}0.10 \\
(1 \cdot 7)\end{array}$ & 330 & 70 & $26 \cdot 6$ & \multirow{4}{*}{$\begin{array}{c}0.022 \\
(0.374) \\
0.002 \\
(0.035) \\
0.001 \\
(0.022) \\
0.002 \\
(0.035)\end{array}$} & $38 \cdot 0$ & \multirow{4}{*}{$\begin{array}{c}3 \cdot 17 \\
(5 \cdot 34) \\
0.32 \\
(0.56) \\
0 \cdot 15 \\
(0.33) \\
0.31 \\
(0.50)\end{array}$} \\
\hline $120-150$ & $\begin{array}{c}0.095 \\
(1.6)\end{array}$ & 350 & 62 & $2 \cdot 6$ & & $4 \cdot 2$ & \\
\hline $150-180$ & $\begin{array}{l}0.10 \\
(1.7)\end{array}$ & 332 & 66 & 1.5 & & $2 \cdot 3$ & \\
\hline $180-210$ & $\begin{array}{l}0.107 \\
(1.8)\end{array}$ & 330 & 65 & $2 \cdot 2$ & & $3 \cdot 4$ & \\
\hline
\end{tabular}

C inulin, urate $=$ clearance UV urate $=$ excreted urate.

9.8\% given by Steele and Rieselbach (1967). After pyrazinamide, urate clearance fell dramatically to an average of $2.1 \mathrm{ml} / \mathrm{min}$ per $1.73 \mathrm{~m}^{2}$ and the ratio of urate clearance to inulin clearance fell to an average value of $3.3 \%$. The ratio of total secreted urate (UV urate control-minimum UV urate after pyrazinamide) to excreted urate (UV urate control) was $95 \cdot 8 \%$.

Utilizing the data outlined in the Table, calculated tubular secretion of urate was $4.52 \times 10^{-4}$ $\mu \mathrm{mol} / \mathrm{ml}(7.61 \mu \mathrm{g} / \mathrm{ml})$, higher than the normal range of $2.39 \pm 0.02 \times 10^{-4} \mu \mathrm{mol} / \mathrm{ml}(4.01 \pm 0.37 \mu \mathrm{g} /$ $\mathrm{ml}$ ) given by Steele and Rieselbach (1967). The fractional excretion of uric acid was $2 \cdot 27 \%$ and within the normal range of $2 \cdot 15 \% \pm 0.54 \%$ expressed by the same authors. Total urine oxypurines were $45.6 \mu \mathrm{mol} / 1$ and within the normal range of $30-140 \mu \mathrm{mol} / 1$ reported by Klinenberg and others (1967).

\section{Discussion}

The patient described in this report illustrates the vague symptoms with which hyperparathyroidism may present (Mallette and others, 1974). Renal handling of urate is commonly altered in hyperparathyroidism but the usual sequel is a decrease in urate excretion resulting in hyperuricaemia and gout rather than the converse (Scott, Dixon, and Bywaters, 1964). The association of hypouricaemia and hyperparathyroidism in this instance seemed fortuitous and so we were compelled to seek an unrelated explanation for the low serum uric acid values.

Among the subjects described by Ramsdell and Kelley (1973), hyperuricosuric agents were the most common cause of hypouricaemia. None of these could be incriminated in our patient. Theoretically, clofibrate, which has been shown to induce transient hyperuricosuria (Trevaks and Lovell, 1965) mas have contributed to the low serum uric acid durin the period that she received it but there was no strict temporal relationship between this treatment and hypouricaemia. Our investigations excluded xanthinuria, Fanconi's syndrome, and Wilson's disease as possible causes and there was no evidence of liver dysfunction, Hodgkin's disease, or other neoplastic disorders.

The studies showed that the mechanism of hypouricaemia in this case was unquestionably due to increased renal uric acid excretion as manifest by an increased renal uric acid clearance of $29.2 \mathrm{ml} / \mathrm{min}$ per $1.73 \mathrm{~m}^{2}$ body surface area. Apart from a defect of urine concentrating ability which may have been partly related to age (Miller and Shock, 1953), there was no other evidence of renal tubular dysfunction. Increased uric acid clearance was apparent in the face of slightly impaired glomerular filtration as measured by creatinine and inulin clearances. The $N$ fall in creatinine clearance from $92 \mathrm{ml} / \mathrm{min}$ to $61 \mathrm{ml} / \mathrm{min}$ during the interval between admissions may have been attributable to treatment of the hypercalcaemia with oral neutral phosphate (Dudley and Blackburn, 1970).

The marked reduction of urate clearance from an average of $48.9 \mathrm{ml} / \mathrm{min}$ per $1.73 \mathrm{~m}^{2}$ to $2.1 \mathrm{ml} / \mathrm{min}$ per $1.73 \mathrm{~m}^{2}$ after administration of pyrazinamide was similar to the response seen in normal subjects (Steele and Rieselbach, 1967). The fractional excretion of urate of $2 \cdot 27 \%$ was normal, implying 
that the assumed suppression of tubular secretion by pyrazinamide eliminated the abnormally increased urate clearance. The actual tubular secretion calculated from the data obtained during the pyrazinamide suppression test was abnormally increased to $4 \cdot 52 \times$ $10^{-4} \mu \mathrm{mol} / \mathrm{ml}(7 \cdot 61 \mu \mathrm{g} / \mathrm{ml})$ glomerular filtration rate. The validity of these deductions assumes that pyrazinamide almost completely and specifically inhibits tubular secretion and also assumes that urate reabsorption does not occur at sites distal to tubular secretion. In animals at least the active metabolite of pyrazinamide (pyrazinoate) has a biphasic action, inhibiting uric acid excretion at low plasma concentrations but increasing excretion at high concentrations (Weiner and Tinker, 1972; Fanelli and Weiner, 1973). Furthermore, there is increasing evidence that postsecretory reabsorption mechanisms do exist in man (Diamond and Paolino, 1973).

The value and precision of the pyrazinamide test have been reviewed at length in the context of these objections (Steele, 1973). While interpretation of the test must remain tentative until the action of pyrazinamide has been finally ascertained, it seems likely that the low levels of pyrazinoate achieved in man by the standard oral dose of pyrazinamide would be insufficient to inhibit urate reabsorption. The test remains valid as a rudimentary estimate of urate secretion and reabsorption (Rieselbach and Steele, 1974). If postsecretory reabsorption occurs in man, then the effect of pyrazinamide suppression in our patient may alternatively imply a defect of postsecretory reabsorption rather than increased tubular secretion.

Inhibition of excessive urate clearance by pyrazinamide is also characteristic of the reported hypouricaemic states of Hodgkin's disease and Wilson's disease. The dual interpretations of increased tubular secretion or defective postsecretory reabsorption has each been applied to the results of pyrazinamide suppression in these conditions (Bennett and others, 1972; Wilson and Goldstein, 1973; Rieselbach and Steele, 1974). Which of these interpretations can be more accurately stated remains uncertain. Other subjects exhibiting increased urate clearance as an isolated phenomenon have shown little or no response to pyrazinamide (Greene and others, 1972; Sperling and others, 1974), suggesting that in these cases the defect is one involving a failure to reabsorb filtered urate. The patient reported by Simkin, Skeith, and Healey (1973) had an increased urate clearance which although diminished by pyrazinamide, remained higher than the glomerular filtration rate. It is conceivable that this case represented a failure to reabsorb both filtered and secreted uric acid. The two subjects reported by Khachadurian and Arslanian (1973) and Praetorius and Kirk (1950) also had urate clearance values which exceeded glomerular filtration and although the effect of pyrazinamide was not determined, it seems possible that in view of the very high urate clearance, both had the same defect as the patient described by Simkin and others (1973). Rieselbach and Steele (1974) have proposed that these various examples of increased urate clearance reflect different defects of reabsorption and that they lend support to the concept of pre- and postsecretory sites for reabsorption.

Even though the foregoing suggests demonstrable differences in the mechanism of hypouricaemia between our patient and those with an isolated tubular defect reported by others, intriguing similarities remain. The patient described by Khachadurian and Arslanian (1973) had hypercholesterolaemia as did our subject. Of more special interest is the associated hypercalciuria in the patients described by Greene and others (1972) and Sperling and others (1974). The former considered this to be an incidental finding but the latter suggested that the association might represent a previously undescribed syndrome that also included osteoporosis. There was no evidence of primary hyperparathyroidism in either of these cases but it has been suggested recently that increased parathormone levels occur as a secondary event in more than half of patients with idiopathic hypercalciuria (Coe and others, 1973). The influence of parathormone on renal tubular function is now recognized as much more comprehensive than previously thought. In addition to modifying reabsorption of phosphate there is evidence that it has a similar effect on glucose (Halver, 1967), bicarbonate (Muldowney and others, 1971), and amino acids (Short, Elsas, and Rosenberg, 1974). A pathogenetic role for parathormone in Fanconi's syndrome has been proposed (Morris and others, 1970). However, there is no evidence that parathormone may alter tubular reabsorption of urate exclusively. The difference in the results of pyrazinamide suppression between our patient and those with hypouricaemia and hypercalciuria, and the more commonly observed association of hyperuricaemia with hyperparathyroidism, do not suggest any consistent effect of parathormone on tubular transport of uric acid. Any possible relationship between the increased urate clearance and hyperparathyroidism in the patient reported here must therefore remain speculative.

The authors thank Dr. James V. Howard for letting us study the patient, Dr. Richard S. Dillon for making available to us calcium metabolism data, and Dr. Robert S. Fisher for performing many of the laboratory tests presented here. Supported in part by NIH grant RR-107. 


\section{References}

Bennett, J. S., Bond, J., Singer, I., AND Gottlieb, A. J. (1972) Ann. intern. Med., 76, 751 (Hypouricemia in Hodgkin's disease)

Coe, F. L., Canterbury, J. M., Firpo, J. J., and Reiss, E. (1973) J. clin. Invest., 52, 134 (Evidence for secondary hyperparathyroidism in idiopathic hypercalciuria)

Diamond, H. S., AND PAolino, J. S., (1973) Ibid., 52, 1491 (Evidence for a postsecretory reabsorptive site for uric acid in man)

Dudley, F. J., AND BlaCkBURN, C. R. B. (1970) Lancet, 2, 628 (Extraskeletal calcification complicating oral neutral phosphate therapy)

Fanelli, G. M., AND WeINeR, I. M. (1973) J. clin. Invest., 52, 1946 (Pyrazinoate excretion in the chimpanzee. Relation to urate disposition and the actions of uricosuric drugs)

Greene, M. L., Marcus, R., Aurbach, G. D., Kazam, E. S., and Sefgmiller, J. E. (1972) Amer. J. Med., 53, 361 (Hypouricemia due to isolated renal tubular defect. Dalmation dog mutation in man)

GutMan, A. B., AND Yü, T. F. (1957) Ibid., 23, 600 (Renal function in gout)

HALVER, B. (1967) Acta. med. scand., 181, 209 (The tubular transport of glucose as a measurement of parathyroid function)

Healey, L. A., Skeith, M. D., and Simkin, P. A. (1974) Arch. intern. Med., 134, 46 (Hypouricemia, an incidental finding indicating xanthinuria or defective reabsorption of uric acid)

Khachadurian, A. K., AND ARsLanian, M. J. (1973) Ann. intern. Med., 78, 547 (Hypouricemia due to renal uricosuria. A case study)

Klinenberg, J. R., Goldfinger, S., Bradley, K. H., and Seegmiller, J. E. (1967) Clin. Chem., 13, 834 (An enzymatic spectrophotometric method for the determination of xanthine and hypoxanthine)

Lee, D. B., DrinKard, J. P., Rosen, V. J., AND Gonick, H. C. (1972) Medicine, 51, 107 (The adult Fanconi syndrome. Observations on etiology, morphology, renal function and mineral metabolism in three patients)

Liddle, L., Seegmiller, J. E., AND Laster, L. (1959) J. Lab. clin. Med., 54, 903 (The enzymatic spectrophotometric method for determination of uric acid)

Mallette, L. E., Bilezikian, J. P., Heath, D. A., and Aurbach, G. D. (1974) Medicine, 53, 127 (Primary hyperparathyroidism: clinical and biochemical features)

MilleR, J. H., AND SHOCK, N. W. (1953) J. Gerontol, 8, 446 (Age differences in the renal tubular response to antidiuretic hormone)

Morris, R. C., McSherry, E., Sherwood, L. M., and Sebastian, A. (1970) J. clin. Invest., 49, 68a (Evidence of a pathogenetic role of hyperparathyroidism in the renal tubular dysfunction of patients with Fanconi's syndrome)

Muldowney, F. P., Carroll, D. V., Donohoe, J. F., and Freaney, R. (1971) Quart. J. Med., 40, 487 (Correction of renal bicarbonate wastage by parathyroidectomy)

Nordin, B. E. C., AND Bulusu, L. (1968) Postgrad. med. J., 44, 93 (A modified index of phosphate excretion)

Praetorius, E., AND KirK, J. E., (1950) J. Lab. clin. Med., 35, 865 (Hypouricemia: with evidence for tubular elimination of uric acid)

Ramsdell, C. M., AND Kelley, W. N. (1973) Ann. intern. Med., 78, 239 (The clinical significance of hypouricemia)

Rieselbach, R. E., and Steele, T. H. (1974) Amer. J. Med., 56, 665 (Influence of the kidney upon urate homeostasis in health and disease)

Roe, J. H., Epstein, J. H., AND Goldstein, N. P. (1949) J. biol. Chem., 178, 839 (A photometric method for the determination of inulin in plasma and urine)

Schlosstein, L., Kippen, I., Bluestone, R., Whitehouse, M. W., and Klinenberg, J. R. (1974) Ann. rheum. Dis., 33, 308 (Association between hypouricaemia and jaundice)

Scott, J. T., St. J. Dixon, A., AND Bywaters, E. G. L., (1964) Brit. med. J., 1, 1070 (Association of hyperuricaemia and gout with hyperparathyroidism)

Short, E. M., ElsAS, L. J., AND Rosenberg, L. E. (1974) Metabolism, 23, 715 (Effect of parathyroid hormone on renal tubular reabsorption of amino acids)

Simkin, P. A., SkeITH, M. D., AND HeAley, L. A. (1973) Israel J. med. Sci., 9, 1113 (Suppression of uric acid secretion in a patient with renal hypouricemia)

Sperling, O., Weinberger, A., Oliver, I., Liberman, U. A., and DeVries, A. (1974) Ann. intern. Med., 80, 482 (Hypouricemia, hypercalciuria and decreased bone density: a hereditary syndrome)

SteELE, T. H. (1973) Ibid., 79, 734 (Urate secretion in man· the pyrazinamide suppression test)

- - AND RieselBaCH, R. E. (1967) Amer.J. Med., 43, 868 (The renal mechanism for urate homeostasis in normal man)

Trevaks, G., and Lovell, R. R. H. (1965) Ann. rheum. Dis., 24, 572 (Effect of Atromid and its components on uric acid excretion and on gout)

Weiner, I. M., AND TinkeR, J. P. (1972) J. Pharmacol. exp. Ther., 180, 411 (Pharmacology of pyrazinamide; metabolic and renal function studies related to the mechanism of drug induced urate retention)

Weinstein, B., Irrevfrre, F., AND Watkins, D. M. (1965) Amer. J. Med., 39, 520 (Lung carcinoma, hypouricemia and aminoaciduria)

Wilson, D. M., AND Goldstern, N. P. (1973) Kidney Int., 4, 331 (Renal urate excretion in patients with Wilson's disease)

Wrong, O. And Davies, H. E. F. (1959) Quart.J. Med., 28, 259 (The excretion of acid in renal disease) 